\title{
Scale Validation: The Couple in Light of the Birth and Upbringing of a Child with High Risk in Mexico
}

\section{Rosalía Jiménez-Quiroz ${ }^{1}$, Ma de la Paz Conde-Reyes ${ }^{1}$, Angélica Romero-Palencia ${ }^{2}$, Elizabeth Alvarez Ramírez ${ }^{3}$, Martina Angélica Guido-Campuzano $^{1 *}$ and Castro-Soto, Laura ${ }^{4}$}

${ }^{1}$ Department of Pediatric Follow-up, National Institute of Perinatology, Isidro Espinosa de los Reyes, Mexico

${ }^{2}$ Autonomous University of the State of Hidalgo, Mexico

${ }^{3}$ Educational Psychology, National Pedagogical University, Social Psychology, Faculty of Higher Studies, National Autonomous University of Mexico, Mexico ${ }^{4}$ Neonatal Intensive Care Unit, Hospital de la Mujer (Women's Hospital), Mexico

*Corresponding Author: Martina Angélica Guido-Campuzano, Department of Pediatric Follow-up, National Institute of Perinatology, Isidro Espinosa de los Reyes, Mexico.
Received: July 16, 2021

Published: July 28, 2021

(C) All rights are reserved by Martina Angélica Guido-Campuzano., et al.

\begin{abstract}
Introduction: The birth of a high risk child leads to a disruption of psychic processes in the couple due to the morbidity of the neonate, the hospital environment, and an initial long separation from a child with a risk of death, anomalies or sequels. This acquires a traumatic nature, and has persistent emotional effects and symptoms on the couple. After hospital discharge, stress in relation to the child's health slightly decreases and stress related to parenting and daily chores increases. In a couple's relationship, it is common to find insecurity caused by experiences during the perinatal period, as well as all the challenges that must be faced. This activates psychological resources allowing for couple negotiations, understood as communication processes that take place in different settings: the division of domestic chores, parenting, sexuality, control of money and materials, time, personal space and the equilibrium of the couple with other social and affectionate relationships, as well as opportunities for dialogue, mechanisms to establish rules, relationship conditions and difficulties generated by these processes. The above highlights the importance of creating instruments to understand the experience of the couple under these circumstances.
\end{abstract}

Objective: To create and validate an instrument to measure the couple facing a high risk birth and upbringing in Mexico.

Materials and Methods: The sample consisted of 372 participants living as a couple, with children with a high risk birth, who attended the Pediatric Follow-up at the National Institute of Perinatology (INPer), with an age $\mu=34.46$ (SD $=7.87$ ). In an exploratory study using focus groups, the most frequent indicators found were expressed as Likert 5-point statements. Ethical concerns for the investigation with human subjects were considered. The method used for psychometric analysis was the one suggested by ReyesLagunes and Garcia-Barragan (2008). For validation, the exploratory factor analysis with orthogonal rotation (Varimax) was used.

Results: The scale presents Bartlett's test of sphericity of 4924.824 and a Kaiser-Meyer-Olkin (KMO) sample fitness index with a value of 0.941 , indicating a satisfactory factor analysis. As a result of the 7 interactions of the factor analysis, 3 groups of factors were assembled: Positive affection towards the partner, asynchrony and negative communication towards agreements and synchrony and positive communication towards agreements; these explain $51.15 \%$ of the total variance and a global Cronbach's alfa of 0.808 . Correlations between factors were low to moderate and significant, proving the adequate construct validity of the scale.

Conclusion: The design and validation of this instrument allows the observation of the phenomenon, understanding the experience of couples with children with a high risk birth and their upbringing from a familiar and social perspective according to the characteristics of the instrument. This scale will be useful for future investigations.

Keywords: Children; Orthogonal Rotation; Varimax; Mexico 
Life as a couple is characterized by its diversity and transformation throughout time, with different factors contributing to its transformation, including love, relationships with other people, family, culture and life circumstances. These may be determining aspects for the continuity or conflict within the relationship [1].

Researchers explain love from different perspectives being: 1) Behavioral, relating to the protection and manifestation of physical affection between two parties. 2) Cognitive, pertaining the value of love. 3) Attitudinal, which includes thinking, feeling and behaving in a certain way towards the partner. 4) Sentimental, having to do with physiological answers and a favorable attitude [1].

The quality of these characteristics constitutes the environment in which the couple's relationship unfolds [2]. A couple's adequate functioning provides affectionate and social benefits; behaviors and expectations respond to socially transmitted values and beliefs, allowing for every couple to develop a unique relationship [3]. In this way, the couple represents a unit of intake and work, is a source of intimacy, friendship, affection, sexual satisfaction and company, in addition to offering security for the upbringing of children [4].

A couple's maturity is usually influenced by the willingness and capability to be parents [5]. Literature indicates that being a couple is just as important as being parents and it is necessary to learn to combine both tasks without sacrificing either of them $[6,7]$.

Having a child is a significant event in a couple's life cycle. Although it is a normal event, it may cause stress and insecurity, due to multiple changes that occur and require reorganization and adaptation; the inclusion of a new member to the family, the compromise of taking care of the baby, bonding with the baby and the construction of the identities of "mother" and "father" [8]. The birth of a high risk child leads to a disruption of mental processes due to the newborn's morbidity, that could lead to a lengthy hospital stay. This alters the usual couple dynamics. The initial long separation from a child with a risk of death, anomalies or sequels and the biological vulnerability of the newborn acquires a traumatic nature, with enduring emotional effects and symptoms. The couple may experience guilt and feelings of vulnerability in spite of the risk of the birth being over. After hospital discharge, stress related to the child's health slightly decreases and stress related to daily parenting chores increases $[9,10]$. Nevertheless, the effects of medical, biological and psychoemotional risk such as early interaction disorders, the exercise of parental functions and the capacity to face stress will generate a very particular situation in the child's dynamics with his/her parents [11].
These types of experiences begin to create a particular behavior in parents regarding upbringing [11]. It is common to find insecurity in a couple's relationship due to all that was experienced during the perinatal phase, as well as everything that must be faced, activating psychological resources allowing for couple negotiations, understood as communication processes that develop in different settings: the division of daily chores, parenting, sexuality, control of money and material resources, time, personal space and equilibrium of the couple's relationship with other social and affectionate relations, as well as opportunities for dialogue, mechanisms to establish rules, the conditions of the relationship and the difficulties caused by these processes $[9,10]$.

The characteristics of the relationship kept between members of a couple and their performance as father and mother are not independent from each other; quite the contrary, this is, the roles as a couple and father or mother are strongly related. Likewise, the impact of motherhood and fatherhood on couple dynamics influences at least three areas: activities shared by the couple, distribution of roles among them and the satisfaction of the marital relationship [12].

Couple relationships, besides providing a space of solidarity and cooperation, are also governed by power relations. From there stem couple negotiations, which encompass dialogue processes and the opportunities and mechanisms through which rules and agreements are established in the relationship [9].

In light of the birth of a child with high risk, when there is an adequate communication and positive affection in the couple, both tasks of being parents and couple can be combined without sacrificing one of them. The threat of the mother's/child's death may create solid relationships of reciprocity and strengthening of bonds [7].

It is reported that interaction based on listening and communication facilitates the establishment of agreements and the compliance of rules on behalf of the parents. This allows them to establish behaviors and limits towards children born with a high risk, that favour their development in the complex environment that surrounds them [11].

The quality of the relationship between couple/parents promotes their duties in the environment and their children's upbringing. Therefore, couple conflicts are a critical or determining factor that affects the children's adaptation and wellbeing [2].

The beginning of upbringing in the couple is usually the moment when inequalities are accentuated, as well as the period where do- 
mestic chores increase significantly, developing conflicts of interest. Negotiation strategies aim to modify a given power equilibrium and the difficulties these negotiation processes entail $[9,15]$.

The main conflicts that present in the couple include children's education and the stress generated by the responsibility and duties of being parents, since the division of these is fundamental in a couple's relationship [16]. When a member of the couple does not consider them equal and with a fair distribution, conflict may arise in the couple in light of poor negotiations about who of them and what they should each be in charge of within the relationship [9].

When conflicts emerge, couples become particularly susceptible mistakes, considering these behaviors as impossible to solve, experiencing their own behavior as situational and the other's behavior as laudatory. Each member of the couple becomes self-indulgent, concentrating on innocence and guilt, instead of trying to resolve the conflict [16].

In this manner, different philosophies and beliefs concerning education, interpretations that each member of the couple makes about themselves, others, and of situations, are particularly present in periods of conflict, and create greater difficulties in the control of discipline, thus impacting on the expectations the couple have of their children $[9,16]$.

Ardila [17] reports that 55\% of parents of children with a high risk birth have good and functional couple dynamics and the other half have fair and negative dynamics, presenting risk factors to comply with the child's developmental process. On the other hand, literature also reports an association between the quality of the couple's relationship and behavior as parents, especially the implication in upbringing, such as: discipline methods and consistency, which influence the couple's conflicts [2].

When there has been an experience of a high risk birth, there may also be other imbalances due to all that has been lived through [11] and the morbidity of the birth. This creates asymmetry in the couple, causing an inadequate approach to the situation, probably resulting from a breaking of primary affective bonds and the difficulty to carry out parental functions [7], considering that the higher demands and attention required by these children increases the risk of burnout in the couple [10].

Emotional scars left in the couple from the time of birth bring about difficulties in upbringing and may provoke unadaptive behavior in children, who exhibit negative feelings [11]. Another of the conflicts these couples present in their parent roles is the absence of an authority figure. By trying to compensate for the birth experience, these couples have difficulties in establishing limits with their children [13].

Thus in these couples, stress and frustration worsen the quality of relationships among them and with their children, increasing disagreements in upbringing and resulting in conflictive relationships and a lesser capacity to approach daily challenges in an effective way [7].

There are different scales to assess the couple and upbringing, such as:

The Behavioral scale for mothers and fathers of small children, validated by Solís-Cámara, Díaz, Medina, Barranco, Montejano and Tiscareño [18] in Mexico, in which parents respond according to a 4-point Likert scale. It consists of 99 items, and considers the following factors: 1) Expectations of development, with an alpha of 0.96 assesses the age at which parents expect their children to acquire age-appropriate abilities. 2) Upbringing practices, with an alpha of 0.80 assesses activities that promote the child's psychosocial development as a response to behaviors or experiences parents provide for their children. 3) Disciplinary practices, with an alpha of 0.89 assesses behaviors of parents as a response to specific behaviors in children, with the purpose of controlling such behavior [19].

The Inventory of parental behavior by de Merino, Díaz and DeRoma [20] has the following dimensions: hostility/coercion with a reliability of 0.81 , assesses behavior that shows negative affection or indifference towards the child and may imply the use of coercion, threats or physical punishment to influence the child's behavior. One of the additional stress factors stems from the mother's satisfaction with the current partner. This is divided into two factors: 1) Negative emotions with an alpha of 0.74 , accounting for $29 \%$ of variance and 2) Participation of the current partner in upbringing and mother's satisfaction with the couple's relationship in general, accounting for $15.4 \%$ of variance and presenting an alpha of 0.7 . The support/commitment dimension, with a reliability of 0.79 , assesses behavior that proves the father's acceptance of the child through affection, shared activities and instrumental-relational support.

The Communication Facillitators' Scale by Villanueva, RiveraAragón, Díaz-Loving and Reyes-Lagunes [21] assesses the cognitive aspect of communication, what each one thinks facillitates communication with their partner, with an alpha of 0.959 and an explained variance of 61.58. It comprises four factors: 1) Positive attitude, 2) Respect, 3) Complementarity, and 4) Negotiation. 
The Communication Barriers' Scale by Villanueva, RiveraAragón, Díaz-Loving and Reyes-Lagunes [21], assesses the cognitive aspect of communication, what each one thinks about the difficulties of communicating with their partner, with an alpha of 0.951 and an explained variance of 66.02. It comprises six factors: 1) Negative personality, 2) Dishonesty, 3) Monotony, 4) Shyness, 5) Violence, and 6) Insecurity.

The Communication Interactions' Scale by Villanueva, RiveraAragón, Díaz-Loving and Reyes-Lagunes [21], assesses the behavioral sphere through different dynamics that emerge in the couple the moment they interact, with an alpha of 0.881 and an explained variance of $42.69 \%$. It comprises three factors: 1) Self-modification, 2) Equity, 3) Negative Competitive.

When analyzing the scales about couples and upbringing, it is observed that there are different scales about couples and different scales about upbringing, but no scales were found that assess the couple in light of the birth and upbringing of a high risk child in Mexico. Due to its unique characteristics, the items and factors of the revised scales cannot be applied to this population, hence the purpose of this study was to construct and validate a scale of the couple in light of the birth and upbringing of a high risk child in Mexico.

\section{Methods}

\section{Participants}

The sample was selected in an intentionally non probabilistic manner, and was comprised of mothers and fathers of high risk children living as a couple that attended Pediatric Follow-up at INPer. There were a total of 372 participants, 263 (70.7\%) women and $109(29.3 \%)$ men, with an age range of 16 to 61 years of age $\mu=34.46$ (DE = 7.87); the level of studies for the majority of the sample was high school $29.6 \%$ and bachelor $29.3 \%$; regarding occupation, $47.3 \%$ women were housewives and $25 \%$ of men worked a trade. $100 \%$ of the sample lived with their partner and children with $\mu=8$ (DE $=6.76$ ) years of living together and all of them had gone through the experience of the birth of their high risk child/ children.

The Scale of the Couple in light of the birth and upbringing of a high risk child was created from focus groups by Jiménez-Quiroz, Conde-Reyes, Romero-Palencia and Guido-Campuzano [7]. Three categories were obtained from the focus group, using statements from the systemic theory, the couple's psychosocial theory and parental upbringing practices. Judging was carried out by 5 expert judges who supervised the adequacy of the scope of the questionnaire with the wording of the items proposed. Later it was submitted to a validity of content and once accepted by the experts, pilot- ing was carried out with couples of parents of children with a high risk birth. There were no inconvenients regarding instructions or the chosen mode of response, so it was proceeded to elaborate a scale with the particularities of this population, given that the existing scales do not evaluate special characteristics such as high risk birth.

For the scale with five Likert-type response options (Agree, Totally agree, Occasionally, Disagree, Totally disagree), the response options were chosen according to actions that the couple reported carrying out in the upbringing of their high risk child.

\section{Procedure}

The instrument was applied when children attended a consult at the Department of Pediatric Follow-up at INPer. Parents who live together as a couple were invited to participate; the object of the investigation was explained and instructions were given on how to respond to the instrument. Ethical considerations in research with human subjects were considered and informed consent was obtained. The average time of response was 20 minutes.

\section{Results}

A psychometric analysis was used to evaluate the functionality of the items. The following tests were used with the purpose of obtaining levels of validity and reliability of the instrument:

A discrimination analysis of the items was applied according to the method proposed by Reyes-Lagunes and Barragán [22], construct validity was obtained through an exploratory factor analysis of main components with orthogonal rotation and finally the internal consistency coefficients were obtained.

For the discrimination of items a correlation of each item was made with the total scale, discriminating between the lower extreme group and the higher extreme group of the item, obtained through a Student's $t$ test. The frequency and bias of the item were set at 0.5 . From the total of 82 items of the scale, 10 items were eliminated because they did not meet 2 of the 3 required criteria. Given that the Kaiser-Meyer-Olkin test revealed a factorizable matrix $(\mathrm{KMO}=0.941)$, an exploratory factor analysis of main components with a Varimax orthogonal rotation was carried out in order to determine construct validity. The items in the scale obtained communalities higher than 0.40 , indicating they measure the same construct. Factors with a self-value greater than 1 were chosen, accounting for $51.15 \%$ of variance, with a Cronbach Alpha of 0.808 . The final version of the scale consisted of 28 items (See Table 1 ).

Factors that contribute to attitudes associated to the couple's experience and the upbringing of high risk children were defined based on the distribution of the items. The definition of each of the 


\begin{tabular}{|c|c|c|c|c|}
\hline & \multicolumn{4}{|c|}{ FACTORS } \\
\hline & 1 & 2 & 3 & Total \\
\hline I feel closer to my partner to face the bad news we receive since the birth of our child & .776 & & & \\
\hline What we have experienced due to the high risk birth has brought us together as a couple & .773 & & & \\
\hline Knowing we have the life of our child in our hands has united us as a couple & .755 & & & \\
\hline Since our child was born my partner and me have bonded closer together & .734 & & & \\
\hline I learned to value my partner with the experience we went through when our child was born & .699 & & & \\
\hline I have felt my partner's company throughout this experience as parents & .666 & & & \\
\hline We decided to face everything that happens since the high risk birth of our child as a couple & .665 & & & \\
\hline What we lived through during the birth of our child has united us as a couple. & .662 & & & \\
\hline The high risk birth of our child has made us better parents and a better couple & .660 & & & \\
\hline $\begin{array}{l}\text { Being able to talk to our partner about our child's high risk birth and its emotional impact } \\
\text { strengthens the relationship. }\end{array}$ & .659 & & & \\
\hline $\begin{array}{l}\text { My partner and me decide to continue our relationship because we love each other and not } \\
\text { only because of our child's situation. }\end{array}$ & .599 & & & \\
\hline $\begin{array}{l}\text { Since the difficult experience of the birth of our child, I have learned to let my partner know } \\
\text { how important their support is to me. }\end{array}$ & .594 & & & \\
\hline We had to become involved as a family and couple since the birth of our child. & .586 & & & \\
\hline $\begin{array}{l}\text { In spite of our differences as a couple we make decisions related to the upbringing of our } \\
\text { child together }\end{array}$ & .552 & & & \\
\hline We decided to be together as a couple in order to face our child's situation & .506 & & & \\
\hline As a couple we contradict each other and cannot agree in the upbringing of our child & & .757 & & \\
\hline When I ask my child to do something, my partner contradicts me & & .723 & & \\
\hline $\begin{array}{l}\text { I have no authority with my child because my partner does not allow me to exercise it when } \\
\text { he/she is present. }\end{array}$ & & .709 & & \\
\hline $\begin{array}{l}\text { I become desperate with my partner due to differences of opinion regarding the education of } \\
\text { our child }\end{array}$ & & .703 & & \\
\hline As a couple we confuse our child because we don't agree on limits in the house & & .701 & & \\
\hline $\begin{array}{l}\text { Our child takes advantage of the poor communication we have as a couple and this increases } \\
\text { conflict between us. }\end{array}$ & & .620 & & \\
\hline I feel criticized by my partner when I educate our child. & & .594 & & \\
\hline $\begin{array}{l}\text { My partner takes away my authority in front of my child because he/she says the child suf- } \\
\text { fered very much when they were born. }\end{array}$ & & .585 & & \\
\hline I disapprove of my partner's behavior, but I would rather live there than with family. & & .565 & & \\
\hline As a couple we respect each other's beliefs and we take the best for our family relationship. & & & .684 & \\
\hline It is gratifying to know that we coordinate as a couple in guiding our child. & & & .645 & \\
\hline $\begin{array}{l}\text { My partner was present and supportive at every moment during the hospital stay of our } \\
\text { child. }\end{array}$ & & & .636 & \\
\hline My partner supports me when I ask my child to fulfill his duties. & & & .604 & \\
\hline Number of ítems & 15 & 9 & 4 & 28 \\
\hline Accounted variance $\%$ & 25.15 & 17.09 & 8.89 & 51.15 \\
\hline Self-value & 9.88 & 3.08 & 1.35 & \\
\hline Cronbach's Alpha & .922 & .862 & .711 & .808 \\
\hline Mean (SD) & 3.90 & 1.85 & 4.22 & \\
\hline KMO & & & & .941 \\
\hline
\end{tabular}

Table 1: Items and factors of the Scale: The couple in light of the birth and upbringing of a high risk child. 
factors of the scale is presented in table 2 .

\begin{tabular}{|l|c|}
\hline \multicolumn{1}{|c|}{ Factor } & \multicolumn{1}{c|}{ Definition } \\
\hline Positive affec- \\
tion towards \\
the partner \\
$\begin{array}{l}\text { Assesses the experience through feelings of } \\
\text { satisfaction, joy, enthusiasm, union, commu- } \\
\text { nication and confidence, yielding as a result a } \\
\text { desire for affiliation, motivation, achievement, } \\
\text { success, as well as compromise. This speaks } \\
\text { of interest, responsibility and the decision to } \\
\text { remain next to the partner, together with the } \\
\text { intimacy that includes emotional support and } \\
\text { sharing material things, generating respect } \\
\text { and a greater tolerance in the relationship. }\end{array}$ \\
\hline $\begin{array}{l}\text { Asynchrony } \\
\text { and negative } \\
\text { communica- } \\
\text { tion towards } \\
\text { agreements }\end{array}$ & $\begin{array}{c}\text { Assesses in the partner the agreements made } \\
\text { between them when they are not respected } \\
\text { or adhered to. It describes the interpreta- } \\
\text { tion the couple goes through when one of the } \\
\text { members does not consider a parallel or equal } \\
\text { agreed upon and not kept, creating tension as } \\
\text { a couple and parents, affecting functions and } \\
\text { responsibilities, control of discipline, child } \\
\text { behavior and differences in expectations. }\end{array}$ \\
\hline $\begin{array}{l}\text { Synchrony } \\
\text { and positive } \\
\text { tionmunica- } \\
\text { agreements }\end{array}$ & $\begin{array}{l}\text { Assesses the ability to speak, transmitting } \\
\text { information from another's perspective: feel- } \\
\text { ings, thoughts, fears, attitudes towards speak- } \\
\text { ing of agreements, problems and resolving } \\
\text { differences. It is a predictor of enrichment and } \\
\text { ing mutual support, gratification, tenderness } \\
\text { and comprehension. This leads to coordina- } \\
\text { tion in the couple and parents as a team, } \\
\text { with clear roles and functions for each one, } \\
\text { and whose main objective is that of guiding } \\
\text { and accompanying children throughout their } \\
\text { development. }\end{array}$ \\
\hline
\end{tabular}

Table 2: Scale: The couple in light of the birth and upbringing of a high risk child.

Finally, Pearson's analysis of product correlation was used for the factors in the scale. In table 3 it is observed that factors keep an important and significant relationship between them, which indicates that the scale measures what it intended to measure.

\section{Discussion and Conclusion}

Two people who are emotionally tied and live together have certain patterns of interaction that will result in couple dynamics. This determines the relationship, including child development [17], and the response to a high risk birth, which depends on the personality of every member of the couple, the support received, etc. [23]. It will also establish whether dynamics are functional or dysfunctional for the upbringing of children. This is the reason for creating and

\begin{tabular}{|c|c|c|c|}
\hline & F1 & F2 & F3 \\
\hline $\begin{array}{l}\text { F1. Positive affection towards the } \\
\text { partner }\end{array}$ & 1 & & \\
\hline $\begin{array}{l}\text { F2. Asynchrony and negative } \\
\text { communication towards } \\
\text { agreements }\end{array}$ & $-.439^{* *}$ & 1 & ${ }^{*}$ \\
\hline $\begin{array}{l}\text { F3. Synchrony and positive } \\
\text { communication towards } \\
\text { agreements }\end{array}$ & $.552^{* *}$ & $-.449^{* *}$ & 1 \\
\hline $\begin{array}{l}{ }^{* *} \text { The correlation is significant on } \\
\text { level } 0.01 \text { (bilateral) }\end{array}$ & & & \\
\hline
\end{tabular}

Table 3: Correlation of the scale: The couple in light of the birth and upbringing of a child with high risk.

validating the Scale: The couple in light of the birth and upbringing of a child with high risk in Mexican population.

The Scale, obtained from the factorial analysis, was comprised of 28 items, distributed in three factors: 1) Positive affection towards the partner, with 15 items, 2) Asynchrony and negative communication towards agreements with 9 items, 3) Synchrony and positive communication towards agreements with 4 items. Psychometric analyses demonstrated that each factor had adequate reliability indexes, with Cronbach Alpha's superior than 0.700 for one of them, and 0.800 and 0.900 for the rest of them. The scale also has optimal validity of construct indexes, with item values over 0.400 and a variance of over $50 \%$, with concurrent item validity.

The factors obtained in the exploratory factor analysis of this scale, describe and explain couple's experiences derived from the high risk birth and upbringing.

The first factor named positive affection towards the partner assesses the experience through feelings of satisfaction, joy, enthusiasm, union, communication and confidence, yielding as a result a desire for affiliation, motivation, achievement, success [24], as well as compromise. This speaks of interest, responsibility and the decision to remain next to the partner together with the intimacy that includes emotional support and sharing material things [25], generating respect and a greater tolerance in the relationship and the children's upbringing $[7,26]$. This factor resembles the positive attitude factor in the Communication Facillitator's Scale by Villanueva [21], where the way of communicating is characterized by comprehension and affection. However, the Positive affection towards the partner factor emphasizes satisfaction and the desire to remain with the partner in light of the experience of the birth and upbringing of a high risk child. 
The second factor named Asynchrony and negative communication towards agreements assesses in the partner the agreements made between them when they are not respected or adhered to [6]. It describes the interpretation the couple goes through [16] when one of the members does not consider a parallel or equal distribution [9], as well as situations that were agreed upon and not kept, creating tension as a couple and parents, affecting functions and responsibilities, control of discipline, child behavior and differences in expectations $[6,17]$. This factor may resemble the Negative Competitive factor in the Communication Interaction's Scale by Villanueva [21], in which Watzlawick explains that by not being able to change the hierarchich level in the couple, this will cause constant competition between them, giving way to constant opposition. In the same way, the factor hostility/coercion in the Inventory of parental behavior mentions stressing factors that stem from emotional turmoil and upbringing and that lead to the mother's satisfaction with the couple's relationship. The difference with the factor Asynchrony and negative communication towards agreements is that it includes both members of the couple, not just the mother, as well as examines how this asynchrony and negative communication impacts upbringing of children with a high risk birth and not necessarily a couple's conflict.

The third factor named Synchrony and positive communication towards agreements assesses the ability to speak, transmitting information from another's perspective: feelings, thoughts, fears, attitudes towards speaking of agreements, problems and resolving differences. It is a predictor of enrichment and defines compromise in the relationship $[27,28]$ yielding mutual support, gratification, tenderness and comprehension. This leads to coordination in the couple and parents as a team, with clear roles and functions for each one, and whose main objective is that of guiding and accompanying children throughout their development $[6,7]$. This factor is similar to the factors of equity and symmetrical negotiation of the Communication's Interaction scale of the couple by Villanueva [21], in which the factor of equity involves affection, respect and trust, while the factor symmetrical negotiation involves the way of solving and making decisions. The difference with this factor is that synchrony leads to a good communication, negotiation and decision-making in the upbringing of children with a high risk birth.

The couple is located within a biopsychosocial interrelation system tied by bonds. Conflicts and the way of solving them are strongly tied to dialogue between the couple [17]; therefore satisfaction within the relationship and its upkeep require communication. This is of outmost importance, and the lack of ability to communicate in daily life and not identify emotions may hinder the couple's health and happiness [29], influencing the division of responsibilities, care, education and upbringing of children.
With this instrument it is possible to assess what couples in this population experience in upbringing. This makes it possible to make diagnoses in clinical populations for the creation of intervention programs that favor the couple's relationship and an effective upbringing for parents of children with a high risk birth, improving their neurodevelopment.

With this it may be concluded that a valid and reliable instrument displaying a social phenomenon in Mexican population was obtained. This scale is a short instrument, easy to apply, that allows for the observation of what couples experience in light of the birth and upbringing of a high risk child, viewed from an individual and social perspective. Emotional sequalea may be left in the couple in any context, but especially in light of the birth of a high risk child, and may affect their relationship as a couple and the upbringing of their children. A limit to this investigation was that it used non probabilistic sampling, and being the first version of the scale, the results are only applicable to similar samples.

\section{Bibliography}

1. Retana BE and Sánchez R. "Construcción y validación de una escala para medir adicción al amor en adolescents". Enseñanza e Investigación en Psicología 10.1 (2005): 127-141.

2. Cantón-Cortés D., et al. "Antecedentes de las Prácticas de Crianza: El papel de los conflictos entre los Padres". International Journal and Developmental and Educational Psychology. Revista de Psicología 1.1 (2014): 267-274.

3. Iglesias-García MT., et al. "Escala de Comunicación Autopercibida en la Relación de Pareja (CARP)”. Anales de Psicología/Annals of Psychology 35.2 (2019): 314-322.

4. Vera J. "Patrones de Comunicación en Parejas y su Relación con la Satisfacción Marital en Profesores de una Universidad Privada de Asunción". Eureka 8.2 (2011): 200-216.

5. Torres M. "Impacto Emocional del Embarazo de Alto Riesgo". Revista Colombiana de Psiquiatría 33.3 (2014): 285-297.

6. Puerta D., et al. "Ser Padres o Compañeros, un dilema de la familia actual" (2017).

7. Jiménez-Quiroz R., et al. "La Dinámica de Pareja ante la llegada de niños con nacimiento de alto riesgo". En R. Díaz-Loving, L.I. Reyes-Lagunes y F. López-Rosales (Eds.), Aportaciones Actuales a la Psicología Social IV (2018): 2783-2801.

8. Frade J., et al. "Ser padre y ser madre en la actualidad: repensar los cuidados de enfermería en el puerperio". Matronas Profesion 14.2 (2013): :45-51. 
9. Agirre M A. "Negociaciones de Pareja: Los trabajos Domésticos, la crianza y la construcción de la maternidad y la paternidad". Papeles del CEIC 1 (2016): 1-27.

10. Gómez EC., et al. "Dificultades biosociales de la gran prematuridad". Sociedad Española de Neonatología (2012).

11. Jiménez R. "Experiencia sobre la Crianza de padres con niños con nacimiento de alto riesgo". Tesis Maestría. Instituto de Terapia Familiar Cencalli. México (2018).

12. Hidalgo V and Méndez AS. "La pareja ante la llegada de los hijos e hijas. Evolución de la relación durante el proceso de convertirse en padre y madre". Infancia y Aprendizaje 26.4 (2003): 469-483.

13. Hernánez L. "Taller sobre prácticas de Crianza para padres con hijos con alto riesgo al nacer y su influencia en el funcionamiento familiar". Tesis Licenciatura. UNAM México (2019).

14. Moore K., et al. "Parental relationship quality and child outcomes across subgroups" (2011).

15. Botía M C. "Negociar en la vida cotidiana para transformar las relaciones de género: una propuesta teórica”. Papers 95.1 (2010): 119-137.

16. Ramírez A. "Conflictos entre Padres y Desarrollo de los Hijos. Convergencia". Revista de Ciencias Sociales 11.34 (2004): 171182.

17. Ardila M. "Dinámicas de Pareja en Familias Canguro: Diseño de Cuestionario Escala Likert". Tesis Licenciatura. Pontificia Universidad Javeriana (2017).

18. Solis-Camara P., et al. "Estructura Factorial y Propiedades de la Escala de Comportamientos para madres y padres con niños pequeños (ECMP)". Psicothema 14.3 (2002): 637-642.

19. Solis-Camara P., et al. "Valoración Objetiva del Estilo de Crianza y las expectativas de parejas con niños pequeños". Revista Latinoamericana de Psicología 40.2 (2008): 305-319.

20. Merino C., et al. "Validación del inventario de conductas parentales: Un análisis factorial confirmatorio". Persona 7 (2004): 145-162.

21. Villanueva GBT., et al. "La comunicación en Pareja: Desarrollo y Validción de Escalas". Acta de Investigación Psicológica 2.2 (2012): 728-748.

22. Reyes-Lagunes I., et al. "Procedimiento de Validación Psicométrica Culturalmente Relevante: Un ejemplo". En: Rivera, S., Díaz-Loveng, R., Sánches, A., Reyes Lagunes I, editores.
La Psicología Social en México. México: Asociación Mexicana de Psicología Social (2008): 625-636.

23. González F. "Nacer de Nuevo: La crianza de los niños prematuros: La relación temprana y el apego". Cuadernos de Psiquiatría y Psicoterapia del Niño y del Adlescente 48 (2009): 61-80.

24. Moral de la Rubia J. "La escala de afecto positivo y negativo (PANAS) en parejas casadas mexicanas". Ciencia Ergo Sum 8.2 (2011): 117-125.

25. Maureira F. "Construcción y validación de una escala para medir los 4 componentes del amor de pareja”. REV GPU 12.1 (2016): 99-105.

26. Díaz-Loving R and Sánchez AR. "Psicología del Amor. Una visión integral de la relación de pareja”. México. Porrúa (2002).

27. Sánchez R., et al. "El impacto de la comunicación marital". La psicología social en México (1994): 146-153.

28. Díaz-Loving R and Rivera-Aragón S. "Antología Psicosocial de la Pareja”. México: Miguel Ángel Porrúa (2014).

29. García M and Romero A. "Mantenimiento en la relación de pareja: construcción y validación de dos escalas". RIDEP 34.1 (2012): 133-135

\section{Volume 3 Issue 8 August 2021 \\ (C) All rights are reserved by Martina Angélica} Guido-Campuzano., et al. 